\title{
Opportunistic Behavior, External Monitoring Mechanisms, Corporate Governance, and Earnings Management
}

\author{
Linda Wimelda ${ }^{1}$, Agustina Chandra ${ }^{2} *$ \\ ${ }^{1,2}$ Trisakti School of Management, Jl. Kyai Tapa No. 20, 11440, Jakarta, Indonesia
}

\begin{abstract}
Objective - The purpose of this research is to analyze the effect of motivational bonus, leverage, firm size, corporate governance (audit committee's size, the proportion of independent commissioners, institutional ownership, managerial ownership) and free cash flow on earnings management.

Methodology/Techniques - Earnings management is analyzed in this research using the modified Jones model. The population for the research consists of manufacturing companies listed on the Indonesian Stock Exchange (IDX) between 2013-2015. The final sample includes 60 manufacturing companies.

Findings - The result of this study indicate that motivational bonus, leverage, firm size and free cash flow have an influence on earnings management practices. Motivational bonuses and free cash flow as opportunistic behavior also influence earnings management. In addition, leverage and firm size as external monitoring mechanism influence earnings management practices while audit committee size, the proportion of independent commissioners, institutional ownership and managerial ownership as corporate governance practices in companies has no significant effect on earnings management practices. Hence, it is concluded that corporate governance has no effect on earnings management practices in Indonesia.
\end{abstract}

Type of Paper: Empirical.

Keywords: Opportunistic Behavior; External Monitoring Mechanisms; Corporate Governance; Earnings Management.

JEL Classification: G34, G02.

\section{Introduction}

One of the important tools in assessing a company's performance is their financial statements. Based on

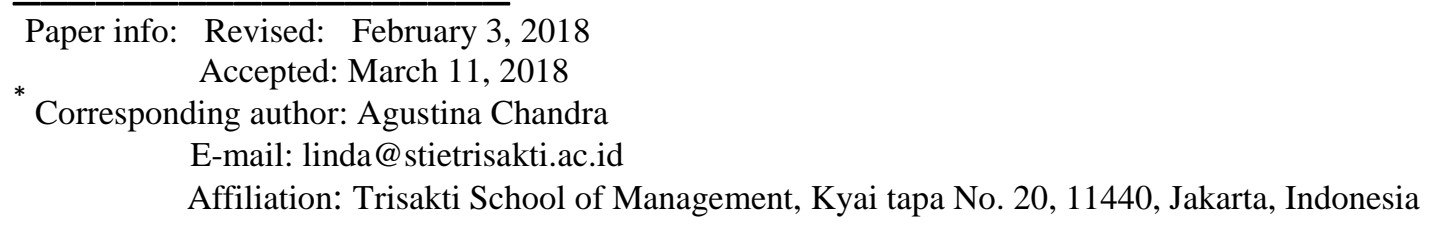


the Indonesian Institute of Accountants (2009) in research conducted by Nurdiniah and Herlina (2015), financial statements are the result of accounting processes that aim to provide information concerning the financial performance of a company, to enable internal and external users to make economic decisions. Earnings information can be used as a benchmark of the success or failure of a company (Susanto et al, 2017). Earnings information also be considered by investors when making investment decisions. The likelihood of gaining a profit through an investment will encourage the management of a company to increase their performance through the manipulation of earnings information; this can be achieved through earnings management. Earnings management is achieved by the management of a company implementing accounting policies aimed at achieving certain goals.

This research seeks to understand the empirical result of the effect of opportunistic behavior, external monitoring mechanisms and corporate governance on earnings management practices in Indonesian companies. Accrual earnings management is a critical issue that has the ability to decrease the credibility of financial statements (Ghazalat et al., 2017). In particular, Indonesia's current economic condition means that most companies are looking to increase their capital by attracting more investors, hence, financial statements are an important tool when making investment decisions. Financial reports should provide an insight to shareholders and potential investors about the financial performance of the company; the presence of earnings management will instead mislead shareholders and unduly influence an investors' decision (Kumari and Pattanayak, 2017).

Following the global financial crisis, the Organization for Economic Cooperation and Development attempted to promote the principles of good corporate governance as a financial stabilizer (Lupu, 2015). Indonesia also tried to promote TARIF (Transparency, Accountability, Responsibility, Independency and Fairness) as corporate governance mechanisms to prevent financial crisis, as it was believed that weak corporate governance was one of the leadings causes of the financial crisis (Roadmap of Corporate Governance, 2014). Corporate governance is a way of monitoring and creating stable agency relationships, to allow company management to align its interest with its shareholders (Al-Faryan and Dockery, 2017). Corporate governance is thought to create transparent information sharing for shareholders. However, a previous study by Kusumaningtias et al. (2016) highlights that some companies in Indonesia have experienced various scandals of corporate governance between 2002 and 2013. This means that scandals or fraudulent behavior still exists, even where a company has implemented various corporate governance principles.

Ghazali et al. (2015) states that if a company has free cash flow, managers have the ability to choose to invest on profitable investments or low-return investments. If managers choose to invest in low-return investments, the company will experience lower growth conditions. This may encourage managers to engage in earnings management to boost their earnings. Meanwhile, Ghazali et al. (2015) has found that when companies have a high profit, managers will be inclined to manage the earnings in a way that derives further benefit from its reported earnings. Management will have less opportunistic behavior for doing earnings management if they are monitored strictly such as through external monitoring mechanisms. Creditors and shareholders act as external supervisors, to monitor and avoid earnings management practices, which is harmful to the company (Ghazali et al., 2015).

\section{Literature Review}

\subsection{Agency Theory}

Agency theory is the theory of the relationship between principal and agent whereby the principal gives some authority to the agent to perform some service on behalf of the principal. These parties often have different interests (Jensen and Meckling, 1976). For present purposes, the principal is the investor or 
shareholders, and the agent is the management of a company. The principal has an interest to obtain bigger returns, whereas management has an interest in obtaining bigger bonuses. This conflict of interest will often trigger management to manage company's earnings for personal gain (Zhou and Elder, 2004). This agency conflict highlights the separation of ownership and control. Management does not have the overall ownership of the company, as this is the role of the shareholders who have provided capital investments in the company.

Shareholders therefore control the activities of management, so that their interests are the primary concern in decision making of the company (Jensen and Meckling, 1976). However, due to their involvement in the day to day operation of the company, management has access to much more information than the shareholders; this is known as asymmetric information (Kidwell et al., 2013). This imperfect information is one of the causes of agency conflict (Gillan and Starks, 2003). This provides an opportunity for management to engage in earnings management practices because asymmetric information between the principal and agent makes it difficult for the principal to control or monitor the agent's behaviors (Palazzo and Rethel, 2007). However, the principal may limit the agent's activities by implementing various incentives and monitoring costs (Jensen and Meckling, 1976).

\subsection{Corporate Governance}

Corporate governance is an important element in improving the efficiency and economic growth of a company as well as improving investor confidence. OECD (2004) has defined corporate governance as a set of relationships between the company's management, the board of the company, shareholders and other relevant stakeholders. Corporate governance is a measurement for controlling the actions of management who are acting as agents of the company (L'Huillier, 2014). Corporate governance also secures a company's assets and increases investment value over a long term period. The board of directors, shareholders and stakeholders will monitor management to decrease the chance of any conflicts of interest between the agent and the principal; corporate governance practices may decrease the practice of earnings management. Man and Wong (2013) believe that corporate governance mechanisms may also reduce agency problems between shareholders and management. This is because corporate governance mechanisms can protect shareholders from the opportunistic behaviors of management such as engaging in earnings management. Earnings management can lead to a decrease in the credibility and relevance of financial information for shareholders' decision making and can cause major financial scandals which may have adverse effects on the marketplace.

Corporate governance mechanism can be divided in two ways: internal corporate governance mechanisms and external corporate governance mechanisms (Man, 2013). External corporate governance mechanisms are determined by external factors, and aim to govern firms in favor of shareholders' interests, such as legal protection and takeover rules. Internal corporate governance is decided by internal factors, such as board structure, board composition, board meetings, audit committees, compensation committee, ownership structure, and institutional shareholders.

\subsection{Hypothesis Development}

Profits reflected in a company's financial statements are used as an indicator of the performance of the company's management. Amertha (2013) states that profits reflect how the management's performance is achieved. A company usually provides bonuses to its employees who reach their profit targets (Nurdianah and Herlina, 2015). Amerta (2013) and Usman and Yero (2012) have found that if a company's profitability (motivational bonus) is high, the probability of earnings management practices in that company will also be high. This is because the company wants to maintain their degree of profitability, to give a positive signal to investors. Ghazali et al. (2015) also found a positive relationship between profitability and earnings management. This means that a company with higher profitability is more likely to have managers that are inclined to engage in earnings management practices to gain a personal benefit. 
Ha1: Motivational bonuses have a positive influence on earnings management.

Ghazali et al. (2015) divides monitoring mechanism into two groups; internal monitoring and external monitoring. Internal monitoring, for example, can be conducted by an internal audit committee and a board of commissioners that will monitor the effectiveness of a company's internal control, to reduce the opportunistic behavior of managers engaging in earnings management. External monitoring can be conducted by creditors or debt holders. Leverage indicates a contract of management and debt holders that measures how assets in a company will be financed by debts. This shows the company's risk to potential debtors (Adrianto, 2014). When a company has high degree of leverage, debt holders will monitor the company closely, so that management do not engage in earnings management (Agustia, 2013 and Oktoviani and Agustia, 2012). Ghazali et al. (2015) states that leverage can be used as an efficient control on earnings management practices.

Ha2: Leverage has a positive influence on earnings management.

A company's size can be measured by the company's total assets or total sales. Siregar and Utama (2005) hypothesize that large companies are less likely to engage in earnings management practices. This is because, due to corporate governance, the company is required to disclose all financial information.

Ha3: Firm size has a negative influence on earnings management.

Zarkasyi (2008) states that an audit committee is chosen by the board of commissioners and is independent from the company. That committee is responsible for monitoring the internal business processes of a company, such as financial reporting by management. The audit committee plays various roles in a company such as to enhance the credibility of financial statements used by shareholders or stakeholders, to actively monitor the quality of work by the internal auditors, and to select better external auditors to improve quality of financial statements and maintain the effectiveness of internal control (Man, 2013). The roles of the audit committee are expected to reduce the opportunistic nature of management, so as to reduce the likelihood of earnings management (Soebyakto et al., 2017). The existence of an audit committee will therefore decrease earnings management practice in a company.

Ha4: The size of an Audit Committee has a negative influence on earnings management.

Commissioners should not be involved in management duties and cannot represent the company when dealing with the third parties (Susanto et al., 2017). Independent commissioners have a duty to monitor the management of a company, including its board of directors, when making decisions for the company (Machmuddah, 2015). The monitoring role of the independent commissioners will decrease the probability of earnings management practices being used. Independent commissioners are more effective when they are independent and have no prior interest in the management of the company (Susanto et al., 2017). Independent commissioners are a tool for monitoring shareholders and guiding management. Beside the role of oversight, the existence of independent commissioners may reduce the possibility of fraudulent financial reporting (Soebyakto et al., 2017).

Ha5: Independent Commissioners have a negative influence on earnings management.

Monitoring functions can also be achieved through the use of institutional investors. This is because institutional investor typically have more power to monitor and control management when acting in the interests of shareholders. Siregar and Utama (2005) define institutional ownership as ownership of a financial 
institution. Financial institutions are capable of monitoring effectively and decreasing earnings management in a given company. Institutional shareholders can ensure the implementation of corporate governance practices due to their fiduciary responsibilities to the beneficial owner (OECD, 2004). Institutional ownership plays a vital role in minimizing earnings management practices within a company however, where there is a high number of institutional shareholders, earnings management practices may still occur (Ghazalat et al., 2017). The fact that institutional shareholders have control of a large portion of votes may enable them to influence corporate behavior and the decisions of the board relating to profitable long term investments (Wang et al., 2011).

Ha6: Institutional ownership has a negative influence on earnings management.

Managerial ownership occurs where a manager or managers own shares in the company by which they are employed. Managers play an active role in the company, for example as directors or commissioners (Susanto, 2013). A manager who holds shares in a company will likely make decisions in the best interests of its shareholders because of their position as a shareholder. They will also motivate management to achieve high quality and performance (Mahariana and Ramantha, 2014). Managerial ownership is one of the corporate governance mechanisms that can be used to reduce the instance of agency conflict. By reducing agency conflict, the quality of reported earnings may increase (Soebyakto et al., 2017). This means that managerial ownership will decrease earnings management practices within a company.

Ha7: Managerial ownership has a negative influence on earnings management.

Based on Gitman and Zutter (2015), free cash flow refers to the amount of cash flow provided to investors after fulfilling all of a company's operational needs, and paying all of its investment and assets. Agustia (2013) and Yogi and Damayanthi (2016) have found that a company that has positive free cash flow will not likely engage in earnings management because the company already has sufficient cash flow. The higher the free cash flow in a company, the better position a company is in. However, Ghazali et al. (2015) presents a different finding; that high levels of free cash flow may in fact provide managers with an increased opportunity to engage in earnings management practices. This occurs when free cash flow is invested in a way that disregards the interests of the shareholders (Jensen, 1986 in the research of Ghazali et al., 2015). With free cash flow, managers can decide where and how to invest, and when managers choose to invest in low-return investments, this leads to a low growth condition, and managers may in turn increase reported earnings (Ghazali et al., 2015).

Ha8: Free cash flow has a negative influence on earnings management.

\section{Research Methodology}

The sample of this research consists of manufacturing companies listed on the Indonesian Stock Exchange between 2013 and 2015, selected using a purposive sampling method. The use of manufacturing companies in this research is to prevent bias in calculating discretionary accruals as a proxy of earnings management. This research uses 60 manufacturing companies, and 178 surveys were obtained. The secondary data is obtained from www.idx.co.id. The data was analyzed using SPSS.

The measurement of each variable is as follows.

Earnings management (EM) in this research will be measured by the modified Jones model (Agustia, 2013). 
TACit $=$ NIit - CFOit

TACit/Ait- $1=\beta 1(1 /$ Ait- 1$)+\beta 2(\triangle \mathrm{REVt} /$ Ait- $)+\beta 3($ PPEt $/$ Ait- $)+$ e.

NDAit $=\beta 1(1 /$ Ait-1 $)+\beta 2(\triangle \mathrm{REVt} /$ Ait-1 $-\Delta \mathrm{RECt} /$ Ait-1 $)+\beta 3(\mathrm{PPEt} /$ Ait- $)$

DAit $=$ TAit $/$ Ait $-1-$ NDAit......

Opportunistic behaviors in this research will be measured by motivational bonuses and free cash flow (Ghazali et al., 2015). Motivational bonuses in this research will be measured using Yogi and Damayanti (2016).

ROA = Net Income/Total Equity.....

Free Cash Flow's measurement is based on Yogi and Damayanthi (2016).

$\mathrm{FCF}=($ Cash Flow Operating - Cash Flow Investing $) /$ Total Assets

External monitoring mechanisms in this research will be measured by leverage and firm size. Leverage is a comparison between debt from creditors and assets. This measurement of leverage is based on research by Nurdiniah and Herlina (2015).

LEV $=$ Total Debts/Total Assets.

Firm Size (SIZE) will be measured by log naturals of total assets based on research by Nurdiniah and Herlina (2015).

Corporate governance in this research will be measured by the size of the audit committee, the proportion of independent commissioners, institutional ownership, and managerial ownership based on Agustia (2013) and Rahmawati (2013).

UKA $=$ Size of Audit Committee

PDKI $=$ Independent Commissioners/Total Commissioners.

KI = Investors' Shares/Outstanding Shares

Managerial ownership (KM) will be measured by dummy variables; 0 means no managerial ownership and 1 means managerial ownership is present.

\section{Results}

The result of the multiple regression linear analysis in this research is shown in Tables 1, 2 and 3.

Table 1. Descriptive Statistics

\begin{tabular}{|l|l|l|l|l|l|}
\hline Variable & $\mathrm{N}$ & Minimum & Maximum & Mean & Standard Deviation \\
\hline EM & 178 & 0,0006 & 0,3454 & 0,54566 & 0,0438002 \\
\hline ROA & 178 & 0,0004 & 0,4018 & 0,090589 & 0,0874772 \\
\hline LEV & 178 & 0,1209 & 0,8809 & 0,421008 & 0,1737683 \\
\hline SIZE & 178 & 25.6195 & 33,1341 & 28,283075 & 1,6355198 \\
\hline UKA & 178 & 2 & 5 & 3,117978 & 0,3870975 \\
\hline PDKI & 178 & 0,2 & 1 & 0,410742 & 0,1311568 \\
\hline KI & 178 & 0,2248 & 0,9825 & 0,684226 & 0,1752943 \\
\hline
\end{tabular}




\begin{tabular}{|l|l|l|l|l|l|}
\hline FCF & 178 & $-0,2351$ & 0,5522 & 0,156244 & 0,1329540 \\
\hline
\end{tabular}

Table 2. Frequencies of Managerial Ownership

\begin{tabular}{|l|l|l|}
\hline Information & Frequencies & Percentage \\
\hline Does not have managerial ownership & 95 & $53.4 \%$ \\
\hline Does have managerial ownership & 83 & $46.6 \%$ \\
\hline Total & 178 & $100 \%$ \\
\hline
\end{tabular}

Table 3. Test Results

\begin{tabular}{|l|l|l|}
\hline Variable & B (unstandardized coefficient) & Sig. \\
\hline ROA & 0,2126 & $0,017^{*}$ \\
\hline LEV & 0,075 & $0,000^{*}$ \\
\hline SIZE & $-0,004$ & $0,049^{*}$ \\
\hline UKA & $-0,003$ & 0,721 \\
\hline PDKI & $-0,019$ & 0,455 \\
\hline KI & $-0,012$ & 0,526 \\
\hline KM & $-0,005$ & 0,488 \\
\hline FCF & $-0,065$ & $0,044^{*}$ \\
\hline
\end{tabular}

*significance level 5\%

Table 3 shows that motivational bonuses have a positive affect on earnings management, hence Ha1 is accepted. Leverage has a positive affect on earnings management, so $\mathrm{Ha} 2$ is not accepted. Firm size has a negative affect on earnings management, so $\mathrm{Ha} 3$ is accepted. Audit committee size, independent commissioners, institutional ownership, and managerial ownership have no affect on earnings management, so $\mathrm{Ha} 4, \mathrm{Ha} 5, \mathrm{Ha} 6$, and $\mathrm{Ha} 7$ are not accepted. Finally, free cash flow has a negative affect on earnings management, so $\mathrm{Ha} 8$ is accepted.

\section{Discussion}

Motivational bonuses have a positive affect on earnings management and free cash flow has a negative influence on earnings management. Opportunistic behavior can significantly influence earnings management practices amongst Indonesian companies. Demirkan and Platt (2009) in research by Ghazali et al. (2015) state that when managers report good profitability, this may act as an incentive for managers to manage earnings and show the future profitability of the company. Meanwhile, free cash flow negatively influences earnings management. This means that company that has sufficient free cash flow has greater confidence in their financial performance, and hence is less likely to engage in earnings management. Ghazali et al. (2015) found that managers will employ earnings management when free cash flow is low for the sake of the company's going concern. Table 3 also shows that external monitoring mechanisms have a significant effect on earnings management.

In fact, monitoring from debt holders is not effective on decreasing earnings management. When a company has a high degree of leverage, management is more likely to engage in earnings management to decrease the company's risk to investors. From these results, it can be seen that big companies experience 
higher pressure from shareholders to provide a high quality of financial statements, hence management will find it difficult to engage in earnings management. The public attention paid to larger corporations may also decrease the occurrence of opportunistic behaviors by management.

Meanwhile, corporate governance practices in Indonesian companies cannot affect earnings management. In Indonesia, the implementation of corporate governance is not sufficient. Some companies have not adequately applied corporate governance codes based on OECD (2004). Hence, corporate governance (audit committee's size, the proportion of independent commissioners, institutional ownership, managerial ownership) does not influence earnings management practices.

\section{Conclusion}

The findings of this research conclude that opportunistic behavior and external monitoring mechanisms influence earnings management practices in Indonesia. On the other hand, corporate management practices within a company cannot influence earnings management practices. This means that opportunistic behavior contributes to earnings management practices, and external monitoring mechanisms may act to resolve these issues. However, corporate governance is not as effective as expected. Weak or strong corporate governance mechanisms can lead to earnings management. This may be because corporate governance is not comprehensively applied in Indonesian companies. This leads to a decrease in the quality of financial statements and hence trust from shareholders and investors. This research only measures corporate governance using four variables, so it does not sufficiently represent complete corporate governance principles. Further studies may use the Corporate Governance Index for implementation of corporate governance in a company based on OECD (2004).

\section{References:}

Adrianto, R., \& Anis, I. (2014). Effect of Corporate Governance Structure and Debt Contract on Earnings Management Practices on Manufacturing Companies Listed In Indonesia Stock Exchange. e-Journal of Accounting Faculty of Economics Trisakti University, 1, 68-88.

Agustia, Dian. (2013). Influence Factor Good Corporate Governance, Free Cash Flow, and Leverage Against Profit Management. Journal of Accounting and Finance, Vol. 15, No. 1: 27-42.

Al-Faryan, Mamdouh Abdulaziz Saleh., and Dockery, Everton. (2017). Ownership Structure and Corporate Governance: What Does the Data Reveal about Saudi Listed Firms? Corporate Ownership and Control. Volume 14. Issue 4.

Amertha, I. S. P. (2013). Influence Return On Asset On Practice Management Profit With Moderation Corporate Governance. E-Journal of Accounting, 373-387.

Effendi, Muhammad Arief. (2016). The Power of Good Corporate Governance Theory and Implementation. Publisher Salemba Four.

Ghazalat, Anas Najeeb Mosa., Islam, Md. Aminul., and Noor, Idris Bin Mohd. (2017). The Monitoring Role of the External Ownership and Discretionary Accruals. Corporate and Control. Volume 14. Issue 2.

Ghazali, Aziatul Waznah., Shafie, Nur Aima., and Sanusi, Zurai dah Mohd. (2015). Earnings Management: An Analysis of Opportunistic Behaviour, Monitoring Mechanism and Financial Distress. Procedia Economics and Finance 28.

Gillan, S. L., and Straks, L. T. (2003). Corporate Governance, Corporate Ownership, and the Role of Institutional Investors: A Global Perspective. Journal of Applied Finance. Volume 13. No. 2.

Gitman, Lawrence J., and Chad J. Zutter. (2012). Principles of Managerial Finance. United States of America: Pearson. Jensen, Michael C., and William H Meckling. (1976). Theory of the Firm: Managerial Behavior, Agency Cost and Ownership Structure. Journal of Financial Economics, Vol. 3, No. 4: 305-360.

Kidwell, D. S., David, W. B., David, A. W., and Richard, W. S. (2013). Financial Institutions, Market and Money: Eleventh Edition. Singapore: John Wiley. 
Kumari, P., \& Pattanayak, J. K. (2017). Linking earnings management practices and corporate governance system with the firms' financial performance: A study of Indian commercial banks. Journal of Financial Crime, 24(2), 223 -241.

Kusumaningtias, Rohmawati., Ludigdo, Unti., Irianto, Gugus., and Mulawarman, Aji Dedi. (2016). Rethinking of Corporate Governance. Procedia Social and Behavioral Sciences 219.

L'Huillier, Barbara Marie. (2014). What Does “Corporate Governance Actually Mean?”. Corporate Governance. Volume 14. Issue 3.

Lupu, Iulia. (2015). The Indirect Relation between Corporate Governance and Financial Stability. Procedia Economics and Finance 22.

Machmuddah, Z. (2015). Corporate Governance Mechanisms, Profit Management and Financial Performance. Indonesia Accounting Research Journal, 3 (1).

Mahariana, I. D. G. P., \& Ramantha, I. W. (2014). The Influence of Managerial Ownership and Institutional Ownership On Manufacturing Profit Management of Companies in Indonesia Stock Exchange. E-Journal of Accounting.

Man, Chi-Keung., and Wong, Brossa. (2013). Corporate Governance and Earnings Management: A Survey of Literature. Journal of Applied Business Research.

Nurdiniah, Dade., and Herlina, Linda. (2015). Analysis Of Factors Affecting The Motivation Of Earnings Management In Manufacturing Listed In Indonesia Stock Exchange. Research Journal of Finance And Accounting. Vol.6, No.3.2015 Oktovianti, Tirza., and Agustia, Dian. (2012). Influence Of The Internal Corporate Governance And Leverage Ratio To The Earning Management. Journal of Basic And Applied Scientific Research.

Organisation for Economic Co-Operation and Development (OECD). (2004). OECD Principles of Corporate Governance. www.oecd.org/dataoecd/32/18/31557724.pdf. (12 November 2015)

Finance, O. J. (2014). Roadmap Corporate Governance Indonesia: Towards Better Public Companies and Issuers. Jakarta: OJK.

Pallazo, G., and Rethel, L. (2007). Conflicts of Interest in Financial Intermediation. Journal of Business Ethics. Volume 81.

Rahmawati, Hikmah Is'ada. (2013). Pengaruh Good Corporate Governance (GCG) Terhadap Manajemen Laba Pada Perusahaan Perbankan. Accounting Analysis Journal. Vol 2, No: 1.

Siregar, Sylvia Veronica., Siddharta Utama. (2005). Influence of Ownership Structure, Company Size, and Corporate Governance Practice on Earning Management. National Symposium on Accounting. SNA. 8 Solo, 15-16 September 2005.

Soebyakto, Bambang Bemby., Dewi, Kencana., Mukhtaruddin., and Arsela, Shendy. (2017). Investment Opportunity Set to Earning Quality and Firms's Value: Corporate Governance Mechanism as Moderating Variable. Corporate Ownership and Control. Volume 14. Issue 4.

SUSANTO, Y. K. (2013). The Effect Of Corporate Governance Mechanism On Earnings Management Practice (Case Study on Indonesia Manufacturing Industry). Jurnal Bisnis dan Akuntansi, 15(2), 157-167.

Susanto, Yulius Kurnia., Pradipta, Arya and Djashan, Indra Arifin. (2017). Free Cash Flow and Earnings Management: Board of Commissioner, Board Independence and Audit Quality. Corporate Ownership and Control. Volume 14, Issue 4.

Usman, Hassan Shehu., and Yero, Jibril Ibrahim. (2012). Ownership Concentration and Earning Management Practice of Nigerian Listed Conglomerates. American International Journal of Contemporary Research. Vol.2, No.7.

Wang, Timothy., Elsayed, Mohamed., and Ahmed, Abdullahi D. (2011). Corporate Governance and Institutional Ownership: A Critical Evaluation and Literature Survey. Corporate Ownership and Control. Volume 9. Issue 1.

Wimelda, Linda and Siregar, Sylvia Veronica. (2017). The Effect of Financial Institution Ownership on Firm Value. Corporate Ownership and Control. Volume 14, Issue 2.

Yogi, L. M. D. P., \& YOGI, L. M. D. P. (2016). Influence of Free Cash Flow, Capital Adequacy Ratio and Good Corporate Governance on Profit Management (Doctoral dissertation, Udayana University).

Zarkasyi, Moh. Wahyudin. (2008). Good Corporate Governance In Manufacturing Enterprises, Banking and Other Financial Services. Bandung: Alfabeta.

Zhou, Jian., and Elder, Randal. (2004). Audit quality and Earning Management by Seasoned Equity Offering Firms. Asia Pacific Journal of Accounting And Economics. Vol. 11 No.2:95-120. 